\title{
The Effectiveness of Play Therapy in Hospitalized Children with Cancer: Systematic Review
}

\author{
Hajaratul Azwaningsih Ibrahim, Arbiyaningsih, Andi Adriana Amal, Huriati \\ UIN Alauddin Makassar, Indonesia \\ Corresponding author: azwaningsih@yahoo.co.id
}

\begin{abstract}
Background: Play therapy in cancer children is a major intervention that can meet the needs of playing in children who are hospitalized.

Purpose: This study aimed to determine an effective play therapy model given to children with cancer undergoing hospitalization.

Methods: The research design used is quantitative descriptive with a Systematic Review approach. Data collection techniques using article search sources in this study are Pubmed, Science Direct, Google Schoolar, Portal Garuda, JOIN, IJSR, and Emerald. Articles published from 2015-2019 and focus on play therapy interventions in children suffering from cancer.

Results: The results of the analysis of nine articles in accordance with the inclusion criteria about play therapy in children with cancer proved effective in reducing hospitalization of children. The play therapy used in the selected article is drawing, painting, puzzle, storytelling, cognitive behavior and therapeutic play with 20-60 minutes of execution time.

Conclusion: The play therapy is recommended for use because the technique is simple, does not require a lot of tools and materials, is easy, affordable and can be done by children with preschool and school-age cancer who are hospitalized.
\end{abstract}

Keywords: Children, Hospital, Cancer, Play Therapy. 


\section{BACKGROUND}

Cancer is a disease that is the leading cause of death worldwide. Cancer is a leading cause of death for children, with 300,000 new cases diagnosed each year. Children with cancer in low and middle income countries have a four times greater risk of death than high income countries (WHO, 2018).

The most common cancers in children are acute lymphoblastic leukemia (ALL) (26\%), brain tumors and central nervous system (CNS) (21\%), neuroblastoma (7\%), and non-Hodgkin's lymphoma (6\%). Hodgkin's lymphoma (HL) (15\%), thyroid carcinoma $(11 \%)$, brain and CNS tumors (10\%), and germ testicular cell tumors (8\%) are the 4 cancers most commonly diagnosed in adolescents (Ward E, 2014).

In Indonesia it is estimated that every year there are 4,100 new cases of cancer in children. Basic Health Research (RISKESDAS) in 2018 states that the prevalence of cancer per mile at the age of less than 1 year is $0.03 \%$, ages 1 to 4 years by $0.08 \%$ and ages 5 to 14 years by $0.31 \%$ (Ministry of Health Republic of Indonesia, 2018). Preschool children are ill and the need for children to be hospitalized creates a crisis in their lives.

Data from Dharmais Cancer Hospital states that cases of childhood cancer in Dharmais SSR are likely to increase. The highest increase occurred in 2011, from 63 cases in 2010 to 122 cases in 2011. In 2014, 163 cancer cases were found in children in the Dharmais SSR with the most cancers, Leukemia, with 46 cases (Ministry of Health Republic of Indonesia, 2013).

Efforts to improve child health are supported by the Indonesian government through Law No. 23 of 1992 in article 17 which emphasizes that children's health is organized to realize the growth and development of children. Efforts to improve children's health starts from the time in the womb, infancy, infancy, pre-school age and school age (Health Law No. 23 of 1992).

Children with cancer who undergo hospitalization have effects including separation from family and friends, undergoing painful treatment, being in an unfamiliar environment, and missing out on playing opportunities. Children with cancer will experience pain related to the disease process and treatment, visible side effects such as hair loss, weight loss, physical disability, negative impact on the child's social, and psychological adjustment. Children with cancer may experience very severe anxiety, withdrawal, behavioral problems, excessive somatic complaints, stress, frustration around them, and difficulty in relationships with peers (Elfira, 2011).

Preschoolers' responses to illness and hospitalization can cause them to see that both things are a punishment and cause children to fear invasive actions (Adriana, 2013). Preschoolers see hospitalization as a frightening experience. When the child is undergoing treatment in the hospital, usually the child will be prohibited from moving a lot and must rest a lot. This disappoints the child so that it can increase anxiety in children (Saputro, 2017). Various strategies can be used to help children adjust to the hospital environment, one of them with play therapy.

Playing in the hospital besides being an effective media to adapt can also provide several benefits, which can improve the relationship between children, families and nurses, can restore feelings of independence in children, provide feelings of pleasure, and help children express feelings of anxiety, fear, sadness, tension and pain ( $\underline{\text { Suza, 2015). }}$.

Playing for children is a necessity. When a child is ill and must be treated in a hospital, the need to play should still be facilitated. But in children with cancer not all types of games can be done. To support the treatment process, playing in a hospital must meet the requirements including a child not using much energy to avoid fatigue, playing 


\section{Journal Of Nursing Practice}

http://thejnp.org

ISSN: 2614-3488 (print); 2614-3496 (online)

Vol.3 No.2. April 2020. Page.233-243

time is shorter, playing instruments used are simple, relatively safe, do not interfere with children's rest and do not conflict with the therapeutic program (Yuliastati, 2016).

Play is an activity that can be done by children as an effort to stimulate their growth and development and playing in children in the hospital becomes a medium for children to express feelings, relaxation and distraction of uncomfortable feelings. Nurses can help parents deal with problems related to the care of their children in the hospital because the nurse is beside the patient for 24 hours. The focus of nursing interventions is to minimize psychological support in child family members. One nursing intervention in overcoming the impact of hospitalization on children is by providing play therapy. Play therapy can be done before performing a procedure on a child, this is done to reduce the tension and emotions felt by the child during the procedure. One alternative to divert the attention of children who are hospitalized is by supporting the means of play that can facilitate children to reduce anxiety and fear preschoolers who are hospitalized, because preschoolers still enjoy playing (Huda, 2014).

Many play media to reduce the impact of hospitalization on children. In this study, we want to explain further how effective game media are used by nurses in hospitalized children with cancer and the extent to which outcomes are generated using systematic review as an analysis tool.

\section{OBJECTIVE}

This study aimed to determine an effective play therapy model given to children with cancer undergoing hospitalization

\section{METHODS}

The design in this research was / The design of this research is quantitative descriptive with a Systematic Review approach. The research strategy of this research article by using relevant keywords and terms that are mostly used and referring to the terms contained in MeSH (Medical Subject Headings) are "Hospitalization, Play therapy, Child, Children, Cancer, Hospitalized, Child Hospitalized, Children Hospitalized, Hospitalized Child, Anxiety, Pediatric cancer" the source of the search database used in this research are Pubmed, Science Direct, Google Schoolar, Portal Garuda, and JOIN, IJSR, dan Emerald.

The study included for this literature review is an article published in the last 5 years of 2015-2019, there is volume or ISSN, using experimental design and focusing on play therapy interventions in children suffering from cancer. 9 articles were obtained that fit the criteria, and based on the evaluation with Duffy's Research Appraisal Checklist Approach 9 articles were included in the category of superior paper (Score 205-306).

\section{RESULTS}

1. Respondents' characteristics

Table 1. Respondents' characteristics

\begin{tabular}{|c|c|c|c|c|}
\hline \multirow{2}{*}{ Play therapy } & \multicolumn{2}{|c|}{ Age } & \multicolumn{2}{|c|}{ Gender } \\
\hline & Pre School & School & Male & Female \\
\hline Draw & $\sqrt{ }$ & & $\sqrt{ }$ & $\sqrt{ }$ \\
\hline Paint & & $\sqrt{ }$ & $\sqrt{ }$ & $\sqrt{ }$ \\
\hline Puzzle & $\sqrt{ }$ & & $\sqrt{ }$ & $\sqrt{ }$ \\
\hline Storytelling & & $\sqrt{ }$ & $\sqrt{ }$ & $\sqrt{ }$ \\
\hline Cognitive-Behavior & & $\sqrt{ }$ & $\sqrt{ }$ & $\sqrt{ }$ \\
\hline
\end{tabular}




\begin{tabular}{l|l|l|l|l}
\hline Play Therapeutic & & $\sqrt{ }$ & $\sqrt{ }$ & $\sqrt{ }$ \\
\hline
\end{tabular}

a. Play therapy obtained

1) Of the 9 articles found, there were 3 articles that used drawing play therapy to reduce hospitalization in children with cancer.

2) From 9 existing articles, there were 2 articles that used painting play therapy to reduce hospitalization in children with cancer.

3) Of the 9 articles found, 1 article that uses puzzle play therapy to reduce hospitalization in children with cancer.

4) Of the 9 articles found 1 article that uses storytelling play therapy to reduce hospitalization in children with cancer.

5) Of the 9 articles found, 1 article that uses cognitive behavioral play therapy to reduce hospitalization in children with cancer.

6) Of the 9 articles found, 1 article uses therapeutic play therapy to reduce hospitalization in children with cancer.

b. Drawing Play Therapy

1) The duration of therapy playing drawing is 30 minutes during one game.

2) The procedure of providing drawing therapy is to first measure anxiety in children before bermian therapy is given. After that given the play drawing therapy then the child coloring the picture that has been made. After that, measuring the level of anxiety in children again.

c. Playing Painting Therapy

1) The duration of playing therapy is 25 minutes to 60 minutes.

2) The procedure of providing play therapy by painting is to first measure anxiety in children before being given play therapy. After that, he was given therapy to play painting using watercolors and then after painting the children explained their paintings to researchers and other children. After that, measuring the level of anxiety in children again.

d. Puzzle Play Therapy

1) The duration of therapy playing Puzzle is 20 minutes.

2) The procedure of providing Puzzle play therapy is to first measure anxiety in children before being given play therapy then to be given a Puzzle play therapy with a type of jigsaw puzzle. After that, measuring the level of anxiety in children again.

e. Storytelling Play Therapy

1) The duration of therapy to tell storytelling is 20 minutes.

2) The procedure of giving play therapy with storytelling is to first measure anxiety in children before playing therapy. After that, play therapy is told by storytelling to other children. After that, measuring the level of anxiety in children again.

f. Cognitive-Behavior Playing Therapy

1) The duration of therapy to play storytelling is 60 minutes.

2) The procedure for providing cognitive behavioral play therapy is to first measure anxiety in children before playing therapy. After that the therapist builds a good relationship with the child to eliminate fear and stress on the child, then identifies the child's emotions through a smiley game then the child is asked to express negative emotions and make positive emotions through the guessing game the puppet emotions then the therapist makes the child laugh and joke together. After that, measuring the level of anxiety in children again. 


\section{Journal Of Nursing Practice}

http://thejnp.org

ISSN: 2614-3488 (print); 2614-3496 (online)

Vol.3 No.2. April 2020. Page.233-243

g. Therapeutic Play Therapy

1) The duration of therapeutic play therapy is 20 to 30 minutes.

2) The procedure for providing therapeutic play therapy is to first measure anxiety in children before playing therapy. After that the first game uses a chemo duck doll that uses a bandana, iv catheter, arm bandage and a surgical scrub then the children play by practicing treatments or procedures at the hospital using the doll. The second game uses a booklet which is a coloring book with caricature drawings shaped like a syringe and an infusion set that has been modified so that the shape does not make the child feel scared, then the child plays with coloring the caricature picture. After that, measuring the level of anxiety in children again.

\section{DISCUSSION}

The results of 9 articles on play therapy in handling hospitalization in children with cancer prove that play therapy is effective in overcoming the problem of hospitalization in cancer patients. The 9 articles show that play therapy can be done at preschool and school age, although different types of age of the child but the results of the study still say that play therapy is effective given. If there are studies using different methods and ages, it is possible that the results found can be different and can be the same.

The sampling technique used in the article is the average using purposive sampling. The sampling technique is in accordance with the studies in the article because to determine the sample there must be criteria related to the study. The size of the sample used an average of 14-65 respondents who were then divided into the intervention group and the control group. However, there were 4 journals which had no control group given treatment, so there were differences between the control group and the intervention group. There are 5 journals that use 1 group, namely the intervention group. Based on statistical tests in the article using the Wilcoxon test and Independent Test T-test which shows there is an effect of play therapy in dealing with hospitalization in children with cancer. These results indicate that effective play therapy is given to children because it can reduce hospitalization problems that are common in pediatric patients suffering from cancer.

In the intervention group given play therapy with a time of 20-60 minutes. According to Adriana (2013) which states that the time for playing therapy is 30-35 minutes consisting of the 5 minute preparation stage, the 5 minute opening stage, the 20 minute activity stage and the 5 minute closing stage. Meanwhile, according to Vanfeet $\underline{(2011)}$ the time needed for play therapy in children who are hospitalized is 15-20 minutes. 15-20 minutes can make closeness between parents and children and does not cause children to fatigue due to play.

Based on selected journals effective play therapy is used to overcome hospitalization in children with cancer, namely:

1. Drawing Play Therapy

Based on the analysis results of drawing play therapy proved to be effective in reducing anxiety in children with cancer. From the results of this study prove that playing with drawing can make children become comfortable and provide a relaxing and distracting effect on children. This is in line with Ningsih's research (2015) which states that before being given playing therapy the patient's anxiety level is higher than after being given play therapy.

In addition, this study is also in line with research conducted by Elfira (2011), namely the anxiety of children who are hospitalized decreases after being given play 


\section{Journal Of Nursing Practice}

http://thejnp.org

ISSN: 2614-3488 (print); 2614-3496 (online)

Vol.3 No.2. April 2020. Page.233-243

therapy. Play activities undertaken by nurses in children in the hospital will provide benefits to improve the relationship between patients and nurses and will also help express thoughts, anxiety, fear, sadness, tension and pain.

According to Susanti (2017) play is an activity that children can do as an effort to stimulate their growth and development. Play activities are a reflection of physical, intellectual, emotional and social abilities. Play is a good medium for learning because by playing, children will speak or communicate, learn to adapt to the environment, do what they do and recognize time, distance, and sound so that it will stimulate and will reduce anxiety.

Anxiety is the most common response occurring in children with cancer and undergoing treatment. Normally anxiety can occur as part of the disease and treatment in cancer sufferers. Anxiety can be reactive and situational related to fear after being diagnosed with the disease and during treatment. Besides anxiety in children can arise as an impact that occurs from treatment and during treatment procedures such as anemia, stomatitis, malaise, nausea, vomiting, lethargy, weakness, inactivity, skin discoloration, pain, fear, hair loss, changes in body image patient, even anxious about death (Saputro, 2017).

This anxiety disorder involves anatomical structures in the brain, an aspect that explains anxiety disorders is the influence of the hormone ephineprin. The ephineprin hormone is an adrenaline hormone, this hormone is released in response to stress through the synthesis of catecholamines such as ephineprin. Children who experience stress or anxiety the hormone ephineprin in their body will increase due to an increase in oxygen and glucose to the brain and muscles by increasing heart rate (Ningsih, 2015). Children who experience anxiety can be given play therapy to reduce the hormone ephineprin which increases, after given play therapy there is a decrease in anxiety.

The author assumes that play drawing therapy plays an important role in reducing children's anxiety because playing children can express feelings, anxious thoughts, fear, sadness, tension, and pain. This is consistent with the theory that play therapy is the use of games as an effective medium to help patients prevent or resolve psychosocial difficulties achieving optimal growth and development through exploration and self-expression.

2. Playing Painting Therapy

Based on the research results of playing painting therapy proved effective in reducing anxiety in children with cancer. This is in line with research Chari (2013) shows that play therapy is effective in reducing anxiety in children with cancer and play can be used as an effective intervention by health workers to help children diagnosed with cancer in reducing anxiety.

Anxiety in young children can have an impact on aspects of the child's personal social development. This is consistent with the opinion of the American Cancer Society (2016) where in clients with a young age, this anxiety will affect the child's relationship with others. There are several ways to overcome anxiety one of which is by playing. In children playing is a daily activity that they always do so that playing is a suitable means of therapy to reduce anxiety in children.

Playing in the hospital besides being an effective media to adapt can also provide several benefits, which can improve the relationship between children, families and nurses, can restore feelings of independence in children, provide feelings of pleasure, 


\section{Journal Of Nursing Practice}

http://thejnp.org

ISSN: 2614-3488 (print); 2614-3496 (online)

Vol.3 No.2. April 2020. Page.233-243

and help children express feelings of anxiety, fear, sadness, tension and pain (A'diilah, 2016).

The author assumes play for children is a necessity. When a child is ill and must be treated in a hospital, the need to play should still be facilitated. But in children with cancer not any type of game can be done. One of the games that can be given is to play with painting because children do not use much energy to avoid fatigue, play time is shorter and the instruments used are simple.

3. Puzzle Play Therapy

Based on the research results, Puzzle Play therapy has proven to be effective in reducing anxiety in children with cancer. This can be caused because the child feels happy after doing puzzle play therapy so that the child feels comfortable in the hospital environment. This is in line with research conducted by Kaluas (2015) which states that puzzle play therapy has a significant effect in reducing the impact of hospitalization on children.

The implementation of puzzle play therapy is carried out jointly with other children so that when the child begins to not be interested in continuing to play puzzle, the child will feel challenged when he sees the child next to him almost finished compiling the puzzle. This is evidenced when the other child is almost finished putting together the puzzle pieces, the child will be back excited to continue compiling his puzzle. Some children who at first did not greet each other will eventually interact when one of them first finishes the puzzle game. The child who feels defeated will challenge his friend again to rearrange the puzzle.

Along with this the child will unwittingly interact with friends his age. Based on this, it is expected that children will not just be quiet anymore in the room but can invite other children to talk when they start to get bored so that the stage of psychosocial development of children can walk even if the child is being treated.

One of the games that can be done in preschoolers is by playing puzzles. According to Ball et. al (2012) puzzle is a play tool that can help psychosocial development in preschool children. Puzzle games have a distracting effect on children so that children will focus more on puzzle games rather than the anxiety they feel. The benefits of playing puzzles in reducing anxiety have been proven from several studies. One example is a study by Ramdaniati (2016) where after being given an anxiety puzzle playing therapy in preschool children who are undergoing hospitalization has decreased.

According to the authors of puzzle play therapy can be used as a play option to reduce levels of anxiety in preschoolers who undergo chemotherapy. Besides having the benefit of reducing anxiety levels, puzzles can also help the child's psychosocial development, and mental development and creativity of children. Playing puzzles also does not require excessive effort so that children will not be tired when playing.

4. Storytelling Play Therapy

Based on the results of analysis of play therapy with storytelling proved effective in reducing anxiety in children with cancer. Storytelling will help children with cancer reduce their anxiety. Based on research conducted by Susanti (2017), children's anxiety can be reduced by using play activities, one of which is by telling stories. After the intervention is given, children become more comfortable, cooperative, and willing to work together. Anxiety in children also decreases, and this can help the healing process in children. 


\section{Journal Of Nursing Practice}

http://thejnp.org

ISSN: 2614-3488 (print); 2614-3496 (online)

Vol.3 No.2. April 2020. Page.233-243

This is in accordance with research conducted by A'diilah \& Somantri (2016), with children's storytelling activities able to develop their coping abilities to deal with new things and make children stressed. Potter (2016) explains that storytelling is one strategy to shift the focus of children to negative emotions.

Storytelling is also a reframing technique. This technique can change negative emotions in children with more positive emotions. In addition, storytelling can also be used as a relaxation technique to reduce anxiety. The storytelling method is a method that is non-pharmacological, easy, inexpensive, and is an activity that is liked by children.

With storytelling activities, children who experience anxiety show changes in the feelings they experience. The change from loneliness, worry, sadness, fatigue, fear, anger, and crying turned into happy and relaxed after being given storytelling activities (Kanchan, 2015). Another study conducted by Zarei (2013) found that by storytelling, researchers could reduce all aspects of physical anxiety, worries, and social anxiety experienced by children of age schools that are undergoing treatment at the hospital.

According to the authors effective storytelling activities are given to children with cancer as an alternative activity for children playing while in hospital, because storytelling is an activity that is easy, affordable, accessible, and is one of the methods favored by children.

5. Behavioral Cognitive Play Therapy

Based on the results of cognitive behavioral play therapy research proven effective in reducing anxiety in children with cancer. Identifying emotions and expressing emotions makes children more able to recognize and manage their emotions. Moreover, it can reduce anxiety in children while in hospital.

This is in line with research conducted by Tjahjono (2015) which says that children who receive play interventions in hospitals show fewer negative emotions and experience lower levels of anxiety than children who receive usual care. LinnardPalmer (2015) states, play is very important for the mental, emotional, and social welfare of children. Like their developmental needs, the need for play does not stop when children are sick or in the hospital.

Conversely, playing in a hospital provides the main benefits of minimizing the emergence of child development problems, besides the goal of play therapy is to create a safe atmosphere for children to express themselves, understand how things can happen, learn social rules and overcome their problems and provide opportunity for children to express and try something new. Meanwhile, according to Vanfleet, et al (2011) play therapy is a form of children's play, where they can relate to others, get to know each other, so that they can express their feelings according to their needs.

According to the authors of effective behavioral cognitive play therapy given to children because it can help children in expressing negative emotions and building positive emotions so as to eliminate fear and stress in children who are cared for in hospital.

6. Therapeutic Play Therapy

Based on the results of therapeutic play therapy research proved effective in reducing anxiety in children with cancer. This is in line with research conducted by William (2005) which says that training through therapeutic games can reduce anxiety levels in children aged 7 to 12 years who will perform surgery.

The same study was also conducted by Saputro (2017) where research conducted on 33 children aged 5 to 12 years showed that playing can reduce anxiety in children 


\section{Journal Of Nursing Practice}

http://thejnp.org

who will undergo a medical examination. Play therapy is a therapy that is given and used by children to deal with fear, anxiety and get to know the environment, learn about the treatments and procedures carried out as well as existing hospital staff.

Play therapy is one of the important aspects of a child's life and one of the most effective tools for dealing with a child's stress when hospitalized, because hospitalization creates a crisis in a child's life and is often accompanied by excessive stress, so children need to play to express fear and anxiety they experience as a coping tool in the face of stress.

According to the authors, therapeutic play can help children deal with anxiety due to medical measures they get while undergoing treatment in the hospital. Because the game that has been modified by researchers can make children more calm in undergoing various medical actions in the hospital.

\section{CONCLUSION}

Based on the results of research from 9 articles stated that effective play therapy in reducing hospitalization in children with cancer including play therapy drawing, painting, puzzle, storytelling, cognitive behavior and therapeutic play that can reduce the impact of hospitalization (reducing anxiety, increasing cooperative behavior, and reduce fear) in children. The play therapy is recommended for use because the technique is simple, does not require a lot of tools and materials, is easy, affordable and can be done by children with preschool and school-age cancer who are hospitalized.

\section{SUGGESTION}

Based on the results of the Systematic Review that has been done about effective play therapy given to children with cancer who are undergoing hospitalization, play therapies like this should be developed in the hospital so that children who are hospitalized can feel calm in a new environment, can be cooperative nurses or doctors who are met every day, besides this therapeutic game can also be carried out at home in order to improve fine motor skills, gross motor skills, language development, and social in children. 


\section{Journal Of Nursing Practice}

http://thejnp.org

ISSN: 2614-3488 (print); 2614-3496 (online)

Vol.3 No.2. April 2020. Page.233-243

\section{REFERENCES}

A'diilah, N., \& Somantri, I. (2016). Efektifitas Terapi Mendongeng terhadap Kecemasan Anak Usia Toddler dan Prasekolah Saat Tindakan Keperawatan. Jurnal Keperawatan Padjadjaran, 4(3). 248-254. https://doi.org/10.24198/jkp.v4i3.287

Adriana, D. (2013). Tumbuh Kembang dan Terapi Bermain pada Anak (edisi 2). Jakarta: Salemba Medika.

American Cancer Society. (2016). Cancer Facts \& Figures 2016. Retrieved February 20, 2020, from https://www.cancer.org/research/cancer-facts-statistics/all-cancer-factsfigures/cancer-facts-figures-2016.html.

Ball, et. al. (2012). Principles of pediatric nursing caring for children fifth edition. New Jersey: Pearson.

Chari, U., Hirisave, U., \& Appaji, L. (2013). Exploring play therapy in pediatric oncology: a preliminary endeavour. The Indian Journal of Pediatrics, 80(4), 303-308. https://doi.org/10.1007/s12098-012-0807-8

Elfira, E. (2011). Pengaruh Terapi Bermain dengan teknik bercerita terhadap kecemasan akibat hospitalisasi pada anak usia prasekolah di ruang perawatan $\underline{\text { RSUP H Adam }}$ Malik Medan.

Huda, M., \& Hadi, N. (2014). Pengaruh terapi bermain terhadap respon kecemasan anak usia prasekolah dalam menjalani hospitalisasi di ruang seruni rumah sakit umum daerah jombang. Jurnal Metabolisme, 3(1), 1-5.

Indonesia, P. R., \& Indonesia, P. R. (1992). Undang Undang No. 23 Tahun 1992 Tentang: Kesehatan. Undang Undang, 23, 1-31.

Kaluas, I., Ismanto, A. Y., \& Kundre, R. M. (2015). Perbedaan Terapi Bermain Puzzle Dan Bercerita Terhadap Kecemasan Anak Usia Prasekolah (3-5 Tahun) Selama Hospitalisasi Di Ruang Anak RS TK. III. Rw Mongisidi Manado. Jurnal Keperawatan, 3(2).

Kanchan, L., Chandra, S. M., \& Aarti, S. (2015). A Randomized Clinical Trial to Evaluate the Effectiveness of Storytelling by Researcher on the Hospitalization Anxiety of Children Admitted in Pediatric Ward of Selected Hospitals of District Patiala, Punjab. International Journal of Science and Research (IJSR), 4(10), 706-709.

Kemenkes, R. I. (2013). Buletin jendela data dan informasi kesehatan. Jakarta: Pusat Data dan Informasi Kementerian Kesehatan RI.

Kementrian Kesehatan. (2018). Hasil Utama Riskesdas 2018. February 20, 2020, from https://www.kemkes.go.id/resources/download/info-terkini/hasil-riskesdas2018.pdf.

Linnard-Palmer, L. (2017). Pediatric nursing care: A concept-based approach. California: Jones \& Bartlett Learning.

Ningsih, E. W. (2015). Pengaruh Terapi Bermain Terhadap Kecemasan Anak Yang Menjalani Kemoterapi. Coping: Community of Publishing in Nursing, 3(1).

Nurlaila., Utami, W., \& Cahyani, T. (2018). Buku Ajar Keperawatan Anak. Yogyakarta: Lutikaprio.

Potter, P. A., Perry, A. G., Stockert, P., \& Hall, A. (2016). Fundamentals of Nursing-EBook. Elsevier health sciences.

Ramdaniati, S., \& Hermaningsih, S. (2016). Comparison study of art therapy and play therapy in reducing anxiety on pre-school children who experience hospitalization. Open journal of nursing, 6(01), 46. http://dx.doi.org/10.4236/ojn.2016.61005 


\section{Journal Of Nursing Practice}

http://thejnp.org

ISSN: 2614-3488 (print); 2614-3496 (online)

Vol.3 No.2. April 2020. Page.233-243

Saputro, H., \& Fazrin, I. (2017). Anak Sakit Wajib Bermain di Rumah Sakit: Penerapan Terapi Bermain Anak Sakit; Proses, Manfaat dan Pelaksanaannya. Forum Ilmiah Kesehatan (FORIKES).

Saputro, H., \& Fazrin, I. (2017). Penurunan Tingkat Kecemasan Anak Akibat Hospitalisasi dengan Penerapan Terapi Bermain. JKI (Jurnal Konseling Indonesia), 3(1), 9-12. https://doi.org/10.21067/jki.v3i1.1972.

Susanti, A. (2017). Pengaruh Story Telling terhadap Tingkat Kecemasan Anak Prasekolah yang Menjalani Hospitalisasi di RSUP Dr. M. Djamil Padang Tahun 2017. JIK (JURNAL ILMU KESEHATAN), 1(1), 44-50. http://dx.doi.org/10.33757/jik.v1i1.26

Suza, D. E. (2015). Family-centered care model untuk menurunkan dampak hospitalisasi anak dengan penyakit kanker di Medan, Sumatera Utara. Idea Nursing Journal, $\underline{6(1), 15-24 .}$

Tjahjono, H. (2015). Pengaruh Terapi Bermain Terhadap Kecemasan Anak Yang Mengalami Hospitalisasi Di Ruang Mirah Delima Rumah Sakit William Booth Surabaya. Jurnal Keperawatan, 4(1), 21-29.

VanFleet, R., Sywulak, A. E., \& Sniscak, C. C. (2011). Child-centered play therapy. New York: Guilford Press.

Ward, E., DeSantis, C., Robbins, A., Kohler, B., \& Jemal, A. (2014). Childhood and adolescent cancer statistics, 2014. CA: a cancer journal for clinicians, 64(2), 83103. https://doi.org/10.3322/caac.21219

William Li, H. C., \& Lopez, V. (2005). Do trait anxiety and age predict state anxiety of school- age children?. Journal of clinical nursing, 14(9), 1083-1089. https://doi.org/10.1111/j.1365-2702.2005.01223.x

World Health Organization. (2018). Cancer. Retrieved February 20, 2020, from https://www.who.int/news-room/fact-sheets/detail/cancer.

Yuliastati \& Arnis Amelia. (2016). Modul Dasar Keperawatan Anak. Jakarta: Kementerian Kesehatan Republik Indonesia.

Zarei, K., Parandeh, M. Z., Seyedfatemi, N., Khoshbakht, F., Haghani, H., \& Zarei, M. (2013). Impact of storytelling on physiological, worry and social anxieties in hospitalized school-aged children. Medical - Surgical Nursing Journal. 2(3-4). 115121. 